\title{
HIV/AIDS PREVENTION BEHAVIOR IN THE COMMUNITY OF MEN WHO HAVE SEX WITH MEN AND INFLUENCING FACTORS
}

\author{
Sugiarto $^{\mathrm{a}^{*}} ;$ Pebriyaman Hanafi $^{\mathrm{b}}$; Novi Berliana ${ }^{\mathrm{c}}$ \\ a,b,cSTIKES Harapan Ibu Jambi ; Tarmizi Kadir 71 ; Jambi 36132 ; Indonesia
}

\begin{abstract}
HIV/AIDS has developed into a global health problem, including in Indonesia. The highest cumulative percentage of AIDS cases by way of transmission in Indonesia is through unprotected sex. Populations at high risk for HIV/AIDS transmission are gay (homosexual). This study aims to determine the description of HIV/AIDS prevention behavior and factors affecting the community of men who have sex with men. This study uses a cross-sectional design. The research sample was 79 male sex men in the city of Jambi. The sampling technique was purposive aside. Data were collected by interview using a questionnaire. Data were analyzed statistically using the chi-square test. Of the 79 respondents whose behavior of HIV/AIDS prevention was not good enough as many as 40 respondents (50.6\%). 34 respondents $(43.0 \%)$ had poor knowledge. Respondents whose attitudes were not good were 41 respondents (51.9\%). 42 respondents (53.2\%) had poor motivation. Statistical test results show that there is no relationship of knowledge with $p$-value $=0.177$, and there is a relationship between attitude and $p$-value $=0.005$ and there is a relationship of motivation with p-value $=0.000 \mathrm{HIV} /$ AIDS prevention behavior in the community of men who have sex with men. The conclusion of the study is attitude and motivation are variables related to HIV/AIDS prevention behavior in the community of men who have sex with men.
\end{abstract}

Keywords: motivation ; HIV/AIDS prevention ; knowledge ; attitude

\section{Introduction}

HIV/AIDS has become a pandemic that worries the world community, because besides not yet found drugs and vaccines for prevention, this disease also has a "window period" and a relatively long asymptomatic phase in the course of the disease. This causes the pattern of development such as the phenomenon of the iceberg. The number of cases from year to year throughout the world continues to increase despite various preventive measures carried out. There is no country that is not affected by this disease (Depkes, 2007).

In the world in 2013, there were 35 million people living with HIV which included 16 million women and 3.2 million children aged $<15$ years. The number of new HIV infections in 2013 was 2.1 million consisting of 1.9 million adults and 240.000 children aged $<15$ years. The number of deaths due to AIDS was 1.5 million

\footnotetext{
*) Corresponding Author (Sugiarto)

E-mail: mas_sugik32@yahoo.com
}

consisting of 1.3 million adults and 190.000 children aged $<15$ years. In Indonesia, HIV AIDS was first discovered in Bali Province in 1987. Until now HIV AIDS has spread in 386 districts/cities in all provinces in Indonesia (Kemenkes, 2014).

Various countermeasures have been made by the government in cooperation with various institutions in the country and abroad. The situation originating from the Directorate General of PP-PL shows a tendency to increase in the number of HIV cases from year to year since it was first reported in 1987 to 2014 by 150.296 people. While AIDS was 55.799 people (Kemenkes, 2014).

The spread of HIV/AIDS will have a devastating effect on overall national development. It not only affects the health sector but also affects the socioeconomic field. Moreover, this disease most commonly occurs in the productive age group. Therefore information about the development of HIV/AIDS cases needs to be kept to get a picture of the 
magnitude of the problem as one of the supporters in prevention and prevention efforts. The problem that is very threatening at this time is the fact that there are men in Indonesia who are oriented or choose to have sex with each other also grow the sex industry. In big cities in Indonesia, sex services provided by transvestites and men who both serve male customers have sprung up, including male sex workers or often called gay (Djoerban, 2011).

Certain lifestyles in homosexuals can be a bad risk to physical and mental health and emotional, such as changing partners in sexual relations (having sex), having unprotected sexual relations (not using condoms), having anal sex, drinking, and drugs. In the gay group sex is usually done anal and anal intercourse can lead to a higher risk of STIs and HIV when compared to vaginal sex. This is due to anal sex will often result in injury to the anus because of the anatomical structure of the anus that is filled with peripheral blood vessels and muscles. So that such a situation would be more risky if having sex without a protector.

As the most hidden sub-community, men who has sex with men among the community is very difficult to reach in HIV and AIDS prevention and treatment programs. Even though they have risky sexual behavior, namely having a sexual partner of the same sex, and often changing sexual partners without using condoms and lubricants (Nursalam, 2009).

According to data from the Jambi City Health Office, particularly those affected by HIV in the male community. The number of male sex in the last two years, in 2016 as many as 30 people and in 2017 as many as 21 people. From the data from the Jambi City Health Office in collaboration with the Kanti Sehati Foundation, there were 443 men who has sex with men registered in 2017.

According to Habasiah (2000) to prevent HIV infection during anal sex, condom use is a must. From various research results about the reasons for not using condoms among gays such as condoms can interfere with sexual relations and relationships become unpleasant, lack of confidence regarding the effectiveness of condoms or condoms are often damaged, narrowness and porous so that condoms do not guarantee contracting HIV. For this reason, serious handling of HIV/AIDS transmission is needed, such as sex abstinence programs, being loyal to partners and using condoms, increasing advocacy to decision-makers to understand and approve the use of $100 \%$ condoms that are mandatory for high-risk community groups, condom management, and lubricant management. which is good by guaranteeing the availability of condoms and lubricants that are easily accessible in a sufficient number of locations (Habasiah, 2001). This study aims to determine the description of HIV/AIDS prevention behavior and factors affecting the community of men who have sex with men.

\section{Method}

This research uses a cross-sectional design. The study was conducted in Jambi City from January 9 to February 09, 2019. The dependent variable in the study was HIV / AIDS prevention behavior while the independent variables were knowledge, attitude, and motivation. The study population was all-male sex males while the study sample was as many as 79 male males. The sampling technique with a purposive sampling technique. The research instrument used was a questionnaire. Data collected by conducting interviews with respondents using a questionnaire that has been provided by researchers. The collected data were analyzed using the chi-square statistical test. Before conducting the interview, the researcher asked the respondent for approval on the willingness to become a respondent using the respondent's consent sheet (inform consent). If the respondent refuses, the researcher looks for respondents who are willing to fill out the consent form.

\section{Result and Discussion}

From 79 respondents there were 40 people $(50.6 \%)$ who had bad behavior in preventing HIV/AIDS. There were 34 people $(43.0 \%)$ who had poor knowledge, 41 people $(51.9 \%)$ had poor attitudes and 42 people $(53.2 \%)$ had poor motivation (Table 1).

Table 1. Results of Univariate Analysis

\begin{tabular}{lcc}
\multicolumn{1}{c}{ Variable } & Frequency & Percentage \\
\hline HIV/AIDS Prevention Behavior & & \\
Not Good & 40 & 50.6 \\
Good & 39 & 49.4 \\
Knowledge & & \\
Not Good & 34 & 43 \\
Good & 45 & 57 \\
Attitude & & \\
Not Good & 41 & 51.9 \\
Good & 38 & 48.1 \\
Motivation & & \\
Not Good & 42 & 53.2 \\
Good & 37 & 46.8 \\
\hline
\end{tabular}


Table 2. Relationship between Knowledge, Attitudes, and Motivation with HIV/AIDS Prevention Behavior.

\begin{tabular}{|c|c|c|c|c|c|c|c|}
\hline \multirow{3}{*}{ Variable } & \multicolumn{4}{|c|}{$\begin{array}{l}\text { HIV/ AIDS Prevention } \\
\text { Behavior }\end{array}$} & \multicolumn{2}{|c|}{ Total } & \multirow[t]{3}{*}{ p-Value } \\
\hline & \multicolumn{2}{|c|}{ Not Good } & \multicolumn{2}{|c|}{ Good } & & & \\
\hline & $\mathrm{n}$ & $\%$ & $\mathrm{n}$ & $\%$ & $n$ & $\%$ & \\
\hline \multicolumn{8}{|l|}{ Knowledge } \\
\hline \multirow{2}{*}{ Not Good } & 2 & 61.8 & 1 & 38.2 & 3 & 10 & \multirow[t]{4}{*}{0.270} \\
\hline & 1 & & 3 & 30.2 & 4 & 0 & \\
\hline \multirow{2}{*}{ Good } & 2 & \multirow{2}{*}{46.7} & 2 & \multirow{2}{*}{53.3} & 4 & 10 & \\
\hline & & & 4 & & 5 & 0 & \\
\hline \multicolumn{8}{|l|}{ Attitude } \\
\hline \multirow{2}{*}{ Not Good } & 2 & 659 & 1 & 341 & 4 & 10 & \multirow[t]{4}{*}{0.005} \\
\hline & 7 & & 4 & & 1 & 0 & \\
\hline \multirow{2}{*}{ Good } & 1 & \multirow{2}{*}{34.2} & 2 & \multirow[t]{2}{*}{65.8} & 3 & 10 & \\
\hline & 3 & & 5 & & 8 & 0 & \\
\hline \multirow{3}{*}{$\begin{array}{l}\text { Motivation } \\
\text { Not Good }\end{array}$} & & & & & & & \multirow{5}{*}{0.000} \\
\hline & 2 & 69 & 1 & 31 & 4 & 10 & \\
\hline & 9 & & 3 & & 2 & 0 & \\
\hline \multirow[t]{2}{*}{ Good } & 1 & 29.7 & 2 & 70.3 & 3 & 10 & \\
\hline & 1 & & 6 & & 7 & 0 & \\
\hline
\end{tabular}

The results of the analysis of the relationship of knowledge with HIV/AIDS prevention behavior is known from 34 respondents whose knowledge is poor as many as $21(61.8 \%)$ have poor H IV/AIDS prevention behavior and $13(38.2 \%)$ people have good HIV/AIDS prevention behavior. While out of 45 respondents with good knowledge, 21 (46.7\%) people have poor HIV/AIDS prevention behavior and $24(53.3 \%)$ people have good HIV/AIDS prevention behavior. Statistical test results revealed that there was no significant relationship between knowledge and HIV/AIDS prevention behavior obtained $\mathrm{p}$-value $=0.270$ (p-Value <0.05).

The results of the analysis of the relationship between attitudes and HIV/AIDS prevention behaviors are known from 41 respondents whose attitudes were not good as many as $27(65.9 \%)$ people had HIV/AIDS prevention behaviors that were not good and as many as $14(34.1 \%)$ people had HIV prevention behaviors/AIDS is good. While from 38 respondents whose attitude was good there were $13(34.2 \%)$ people had poor HIV/AIDS prevention behavior and $25(65.8 \%)$ people had good HIV/AIDS prevention behavior. Statistical test results found that there is a significant relationship between attitude and HIV/AIDS prevention behavior obtained $\mathrm{p}$-value $=0.005$ (p-Value <0.05).

The results of the analysis of the relationship between motivation and HIV/AIDS prevention behavior are known from 42 respondents whose motivation is poor as many as $29(69 \%)$ people have poor HIV/AIDS prevention behavior and $13(31 \%)$ people have good HIV/AIDS prevention behavior. Whereas out of 37 respondents whose attitudes were good there were $11(50.6 \%)$ people who had poor HIV/AIDS prevention behavior, and 39 (49.4\%) people had good HIV/AIDS prevention behavior. Statistical test results found that there was a significant relationship between motivation and HIV/AIDS prevention behavior obtained $p$-value $=0,000(p$-Value $<0.05)$.

Knowledge about health behaviors related to HIV will provide direction for understanding self-protection and health improvement (Moorhead, Johnson, \& Mas, 2004). The results showed that there was no relationship between knowledge and HIV/AIDS prevention behavior, $p=0.270$ ( $p$-value $>0.05)$. The results of the research by Ade Handayani \& Indang Trihandini (2012) show that there is no relationship between the level of knowledge with HIV/AIDS risk behavior in married men and unmarried men (Hamzah, Asrifuddin, \& Akili, 2017). The results of Vicca Rahmayani, Akmal M Hanif \& Susila Sastri's (2013) research shows that there is a relationship between knowledge and prevention of HIV/AIDS transmission ( $p$-value $=0.040$ ) (Rahmayani, Hanif, \& Sastri, 2014). Sugiarto's research results (2019) show that HIV/AIDS prevention behavior among men who has sex with men in Jambi City is due to the lack of information about HIV/AIDS prevention (Sugiarto, 2019). Dwi Ratnaningsih's research results (2015) show that knowledge has a positive influence on HIV/AIDS prevention behavior (Ratnaningsih, 2015). Research (Wulandari, Dewi.Y.I, \& Karim, 2013) shows that respondents who have high knowledge (68.2\%) have good behavior in efforts to prevent HIV/ AIDS. Oktarina, Hanafi \& Budisuar's (2012) research results show that respondents with higher education tend to have good knowledge about HIV/ AIDS prevention behavior (Oktarina, Hanafi, \& Budisuari, 2012).

Theory (Notoatmodjo, 2012) states that behavior based on knowledge will be more lasting or durable when compared to behavior that is not based on good knowledge. The results of the field research showed that most respondents knew how to prevent HIV/AIDS such as how to transmit HIV/AIDS to men who has sex with men, but during sexual intercourse their partners refused to use condoms because it reduced their enjoyment during sex. Although 
this research does not directly conduct studies on those infected with HIV, according to researchers the concept of knowledge is a basic understanding that can apply to all people, of course, always will be exposed to information.

Respondents who have poor knowledge due to lack of information about HIV/AIDS prevention in men who has sex with men, while respondents who have good knowledge may be influenced by various things such as social background, education level, level of exposure to information (from mass and electronic media) and frequency of visits to the nearest health service. Between the level of education and knowledge ideally are interrelated and directly proportional, ie the higher level of education of a person will affect the way of thinking and the ability to receive information, which of course can increase one's knowledge, especially about prevention measures for HIV transmission.

The relationship between attitude and HIV/AIDS prevention behavior shows that there is a significant relationship between attitude and HIV/AIDS prevention behavior in male sex men in Jambi City. Wa Ode Asfah S, Afnal Asrifuddin \& Rahayu (2017) research results show that there is a relationship between attitude and HIV/AIDS prevention measures in female sex workers in Manado City ( $p=0.013)$ (Hamzah et al., 2017). The results of Lastianti's research (2013) show the same thing where HIV/AIDS prevention behavior is influenced by a person's attitude, the better the attitude they have, the better the HIV/AIDS prevention behavior and vice versa the less good the less good the prevention of HIV/AIDS (Lastianti, 2013). Tulung's research (2014) also shows the same thing where there is a relationship between attitudes and HIV/AIDS prevention measures (Tulung, 2014). Wilda Tri Yulisa, Hardisman, and Dien Gusta Anggraini Nursal's research shows the same thing where there is a significant relationship between knowledge and HIV/AIDS prevention behavior (Yuliza, Gusta, \& Nursal, 2019).

The results of the study (Rahman \& Yuandari, 2014) show different things where there is no significant relationship between attitudes with HIV/AIDS prevention behavior on IRT. The results of the study (Kristawansari, 2013) also showed that there was no relationship between attitude and HIV/AIDS prevention behavior. The results of the study (Abhinaja \& Astuti, 2014) showed that housewives in the prevention behavior had an attitude with a moderate category of $(67.8 \%)$.
A positive attitude and awareness of the importance of knowing one's status towards HIV infection are very important to be grown in all communities to be able to prevent and suppress further HIV transmission rates. So when a person (not yet infected with HIV) has become aware of the effects of HIV infection, then he will immediately check himself by carrying out blood tests at the nearest health service unit available for HIV antibody testing service facilities, when he feels he has taken an action at risk of HIV infection without feeling intimidated. The results of the study on the attitude variable questionnaire found that respondents' attitudes were not good, especially in safe sex, including the use of condoms. Many men who has sex with men do not use condoms during sexual intercourse, this is what can lead to the transmission of HIV/AIDS.

The relationship between motivation and HIV/AIDS prevention behavior in men who has sex with men shows that there is a significant relationship between motivation and HIV/AIDS prevention behavior. The results of Wahyu Indratmoko's research (2013) show that there is a relationship between motivation and HIV/AIDS prevention behavior in students of Urban High Schools in Sragen Regency (Indratmoko, 2013). The results of the study (Jambak \& Wahyuni, 2018) show that there is a relationship between motivation and changes in the behavior of HIV/AIDS patients. Respondents who have low behavior are 9.84 times more likely to have poor behavior in behavior change when compared to respondents who have high motivation. The results of the study (Handayani, 2011) showed that there was a significant relationship between motivation and behavior change. Umam, Dewi \& Elita (2011) research shows that most respondents have low motivation in VCT (HIV/AIDS examination service program) (Umam, Dewi, \& Elita, 2015)

The results showed that the men who has sex with men community had less motivation in preventing HIV/AIDS. This is very dangerous to themselves. Therefore, it is expected that the men who has sex with men community will have their awareness or motivation to check with health workers every 6 months so that they do not spread the transmission to others. For this reason, it is necessary to have education and disease recognition for men who has sex with men communities and the surrounding community from health workers.

The obstacle in the field experienced by 
researchers is that it is difficult to meet men sex with men because of their lack of openness and fear of their identity and confidentiality revealed,

\section{Conclusion and Suggestion}

The conclusion in this study is the behavior of HIV/AIDS prevention in the community of men sex with men in the city of Jambi is influenced by the attitudes and motivations of the men who has sex with men. For this reason, it is expected that the Kanti Sehati Sejati Foundation in collaboration with health workers will always provide information to men who has sex with men so that there are no men who has sex with men who do not know how to transmit and prevent HIV AIDS, if HIV is detected they already know what to do such as the need for assistance or treatment.

\section{Acknowledgements}

The authors thank the Kanti Sehati Foundation for granting permission for research in the working area of the Kanti Sehati Foundation.

\section{References}

Abhinaja, I. G. W., \& Astuti, P. A. S. (2014). Pengetahuan, Sikap Ibu Rumah Tangga Mengenai Infeksi Menular Seksual Termasuk HIV/AIDS Serta Perilaku Pencegahannya Di Kelurahan Sanur, Kecamatan Denpasar Selatan, Kota Denpasar Tahun 2013. Community Health.

Depkes. (2007). Situasi HIV/AIDS di Indonesia Tahun 1987-2006. Jakarta: Pusat Data dan Informasi.

Djoerban, Z. (2011). Cegah Sejak Dini. Jakarta: Mahaka Publishing.

Habasiah. (2001). Faktor-Faktor yang Berhubungan dengan Pemakaian Kondom pada Waria di DKI Jakarta Tahun 2000. Universitas Indonesia.

Hamzah, W. O. A., Asrifuddin, A., \& Akili, R. H. (2017). Faktor - faktor yang berhubungan dengan tindakan pencegahan hiv/aids pada wanita pekerja seks di kota manado. Jurnal KESMAS, 7(4).

Handayani. (2011). Faktor-faktor yang Berhubungan dengan Perubahan Perilaku pada Pasien HIV/AIDS di wilayah kerja Puskesmas Jatinangor. Universitas Padjadjaran.

Indratmoko, W. (2013). PENGARUH
PENGETAHUAN, SIKAP, DAN MOTIVASI DIRI TERHADAP PERILAKU PENCEGAHAN HIV/AIDS PADA SISWA-SISWI SMA PERKOTAAN DI KABUPATEN SRAGEN, (434). Retrieved from

http://eprints.ums.ac.id/27226/12/File_A rtikel_publikasi.pdf

Jambak, N., \& Wahyuni, A. (2018). FAKTOR-FAKTOR MEMPENGARUHI YANG Keywords: Behavioral Change, HIV / AIDS Jurnal Mutiara Ners Jurnal Mutiara Ners , 1-10 Jurnal Mutiara Ners. Jurnal Mutiara Ners, 1(1), 1-10.

Kemenkes. (2014). Situasi dan Analisis HIV AIDS. Jakarta: Kementerian Kesehatan Republik Indonesia.

Kristawansari. (2013). Hubungan antara pengetahuan dan sikap supir truk dengan perilaku pencegahan HIV/AIDS (Studi kasus di area pangkalan truk alas roban). Universitas Negeri Semarang.

Kuswati, A., Wahyudi, \& Wijayanti, R. (2015). Penceghan IMS, HIV/AIDS dengan Modul Role Play terhadap Pengetahuan dan Sikap Wanita Pekerja Seksual Langsung. Jurnal Riset Kesehatan, 4(1), 664-669.

Lastianti, S. (2013). Hubungan antara Pengetahuan dan Sikap tentang HIV/AIDS pada Siswa SMK Negeri 3 Tahuna. Universitas Sam Ratulangi.

Notoatmodjo, S. (2012). Promosi Kesehatan dan Perilaku Kesehatan. Jakarta: Rineka Cipta.

Nursalam. (2009). Asuhan Keperawatan Pada Pasien Terinfeksi HIV AIDS. Jakarta: Salemba Medika.

Oktarina, O., Hanafi, F., \& Budisuari, M. (2012). HUBUNGAN ANTARA KARAKTERISTIK RESPONDEN, KEADAAN WILAYAH DENGAN PENGETAHUAN, SIKAP TERHADAP HIV/AIDS PADA MASYARAKAT INDONESIA. Buletin Penelitian Sistem Kesehatan.

Rahman, R. T. A., \& Yuandari, E. (2014). Faktor-faktor yang Mempengaruhi Perilaku Pencegahan HIV/AIDS Pada Remaja, 9(1), $1-12$.

Rahmayani, V., Hanif, A. M., \& Sastri, S. (2014). Hubungan pengetahuan dan sikap dengan tindakan pencegahan penularan HIV AIDS pada waria di Kota Padang Tahun 2013. Jurnal Kesehatan Andalas.

Ratnaningsih, D. (2015). Faktor-Faktor yang 
Mempengaruhi Perilaku Pencegahan HIV/AIDS pada Wanita Pekerja Seks Komersial. Biomass Chem Eng, 49(23-6), 22 -23 .

Sugiarto, S. (2019). HUBUNGAN PENGGUNAAN KONDOM DAN INFORMASI DENGAN PENCEGAHAN HIV/AIDS PADA LAKI SEKS LAKI (LSL). Jurnal Ilmiah Ilmu Kesehatan: Wawasan Kesehatan. https://doi.org/10.33485/jiik-wk.v6i1.157

Tulung, O. (2014). Hubungan antara Pengetahuan dan Sikap dengan Tindakan Pencegahan HIV/AIDS pada Siswa SMK Negeri 1 Tomohon. Universitas Sam Ratulangi.

Umam, H., Dewi, Y. ., \& Elita, V. (2015). dentifikasi karakteristik orang resiko tinggi
HIV dan AIDS untuk mengikuti program voluntary couseling and testing (VCT). Jurnal Online Mahasiswa, 2(1). Retrieved from

https://jom.unri.ac.id/index.php/JOMPSI $\% 0 \mathrm{AK} /$ issue/view/327

Wulandari, Dewi.Y.I, \& Karim, D. (2013). Hubungan tingkat pengetahuan terhadap upaya pencegahan HIV/AIDS pada ibu rumah tangga di RW 5 kelurahan meranti pandak. Jurnal Online Mahasiswa.

Yuliza, W. T., Gusta, D., \& Nursal, A. (2019). Artikel Penelitian Analisis Faktor yang Berhubungan dengan Perilaku Pencegahan HIV / AIDS Pada Wanita Pekerja Seksual di Kota Padang Menurut Joint United Nations Programme on, 8(2), 376-384. 